\title{
新分類（WHO：2005 年）による歯原性腫瘍の臨床統計的検討
}

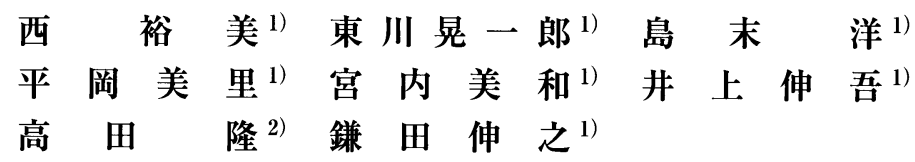

要旨 : 1988 年 4 月から 2005 年 10 月までの 17.5 年間に当科を受診し, 臨床的, 病理組織学的に歯原性腫瘍と診断され た 250 例について，2005 年に改定された菌原性腫晹の新 WHO 分類に基づいて検討した。その結果, 全例が良性腫場 であったがエナメル上皮腫の悪性転化が 1 例あった。㐘牙腫が 68 例と最も多く, 集合性歯牙腫 46 例, 複雑性歯牙腫 22 例であった。次いで, 角化襄胞性菌原性腫場が 55 例, エナメル上皮腫 48 例で, この 3 者で全体の $68.4 \%$ を占めて いた。その他, 腺様菌原性腫瘍 7 例と歯原性石灰化上皮腫 5 例, 石灰化囊胞性菌原性腫瘍 4 例とエナメル上皮線維歯牙 腫 1 例, 間葉性腫瘍グループとして粘夜線維腫とセメント芽細胞腫が各 3 例, 骨関連病変として骨性異形成症 35 例と 骨形成線維腫 7 例, 線維性異形成症 4 例, 単純性骨囊胞・脈瘤性骨囊胞 9 例があった。全体の男女比は $1: 1.14$ とやや 女性に多かった。主訴で最も多かったのは，X線撮影による異常を指摘され精查を求め来院した例が 72 例, 次いで腫 脹 60 例，疼痛 49 例で，歯牙腫では萌出遅延により来院した例が多かった。発生部位では下顎に多く，ほとんどは臼歯 部に発生していたが，左右差はなかった。治療法としては，大部分の症例で腫瘍摘出を行った。摘出後閉鎖創を選択し たエナメル上皮腫 6 例 (31.5\%), 角化囊胞性菌原性腫瘍 4 例（13.3\%）, 骨性異形成症 1 例 (16.7\%), 摘出後開放創を 選択した角化襄胞性䒩原性腫崵 2 例（20.0\%）に再発がみられた。

キーワード：歯原性腫瘍, WHO 新分類, 臨床統計的検討

\section{緒言}

歯原性腫瘍は, 歯を形成する原器や組織に由来する比較 的稀な腫瘍である。一般に腫瘍の発育は緩慢であるが，時 に顎骨の変形や咬合障害をきたすほど増大したり，稀に悪 性転化する例もある。今回われわれは, 当科を受診した歯 原性腫瘍患者について，2005 年に改訂された歯原性腫瘍 の WHO 組織分類に基づいて臨床統計的に検討したので, 若干の文献的考察を加えて報告する。

\section{対象および方法}

対象は 1988 年 4 月から 2005 年 10 月までの 17.5 年間に 広島大学病院口胿顎顔面再建外科を受診し, 臨床的, 病 理組織学的に歯原性腫瘍と診断された 250 例である。新 WHO 分類に基づいて, 性別, 年齢, 主訴, 部位, X 線所 見, 歯牙との関係, 治療法㧍よび再発の有無について検討 した。

\footnotetext{
1) 広島大学大学院 医歯薬学総合研究科 顎口腔䅡部医科学講座 口腔外科学教室（主任：鎌田伸之教授）

2) 広島大学大学院 医歯薬学総合研究科 先進医療開発科学講座 口胿顎顔面病理病態学教室（主任：高田 隆教授）

〔受付 : 2006 年 3 月 1 日, 受理 : 2006 年 3 月 31 日]
}

\section{結果}

\section{1. 疾患別分類 (図 1 )}

250 例全例が良性腫瘍であったが，エナメル上皮腫の 1 例には悪性転化がみられた。

歯牙腫が 68 例 (27.2\%) と最も多く, 集合性歯牙腫 46 例, 複雑性歯牙腫 22 例であった。次いで, 角化囊胞性歯原性 腫瘍が 55 例 (22.0\%), エナメル上皮腫 48 例（19.2\%）で, この 3 者で全体の $68.4 \%$ 占めていた。エナメル上皮腫の 亜型分類は，充実型（多囊胞型）が 34 例 $(70.8 \%)$ ，単囊 胞型が 12 例 (25.0\%), 線維形成型 2 例 $(4.2 \%)$ で, 骨外 型（周辺型）はみられなかった。旧分類で歯原性角化囊胞 とされていたもののうち, 䧶胞壁が錯角化を示すものは角 化囊胞性歯原性腫瘍に名称が変更されたが, 正角化を示す ものはそのまま歯原性角化襄胞に分類されることになる。 当科で歯原性角化囊胞の組織診断を得たうちの 3 例は襄胞 壁の角化重層扁平上皮が正角化を示していたため，歯原性 腫瘍より除外した。その他，上皮性腫瘍グループでは腺様 歯原性腫瘍 7 例と歯原性石灰化上皮腫 5 例, 混合性腫瘍グ ループでは石灰化囊胞性歯原性腫瘍 4 例とエナメル上皮線 維歯牙腫 1 例, 間葉性腫瘍グループでは粘液線維腫とセメ ント芽細胞腫が各 3 例, 骨関連病変では骨性異形成症 35 例と骨形成線維腫 7 例, 線維性異形成症 4 例, 単純性骨囊 胞・脈瘤性骨囊胞 9 例であった。 


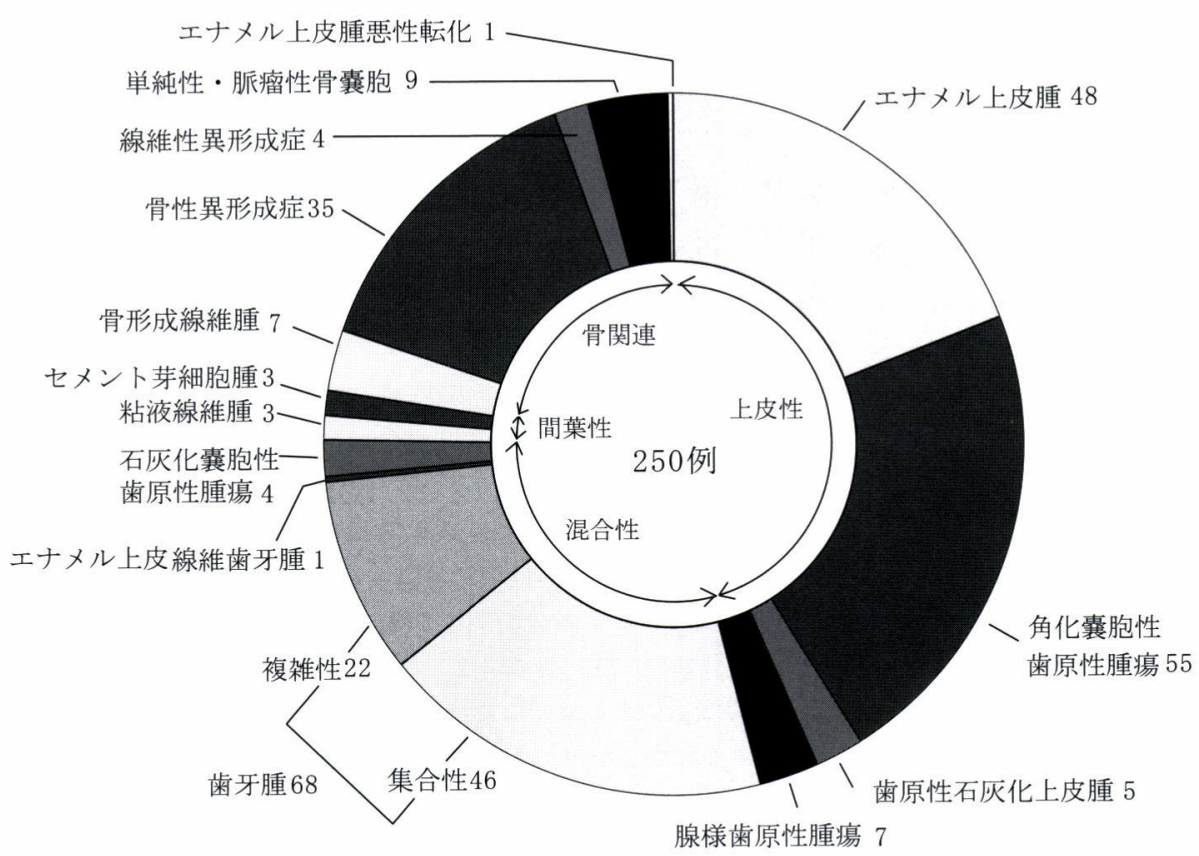

図 1 疾患別分類（例）

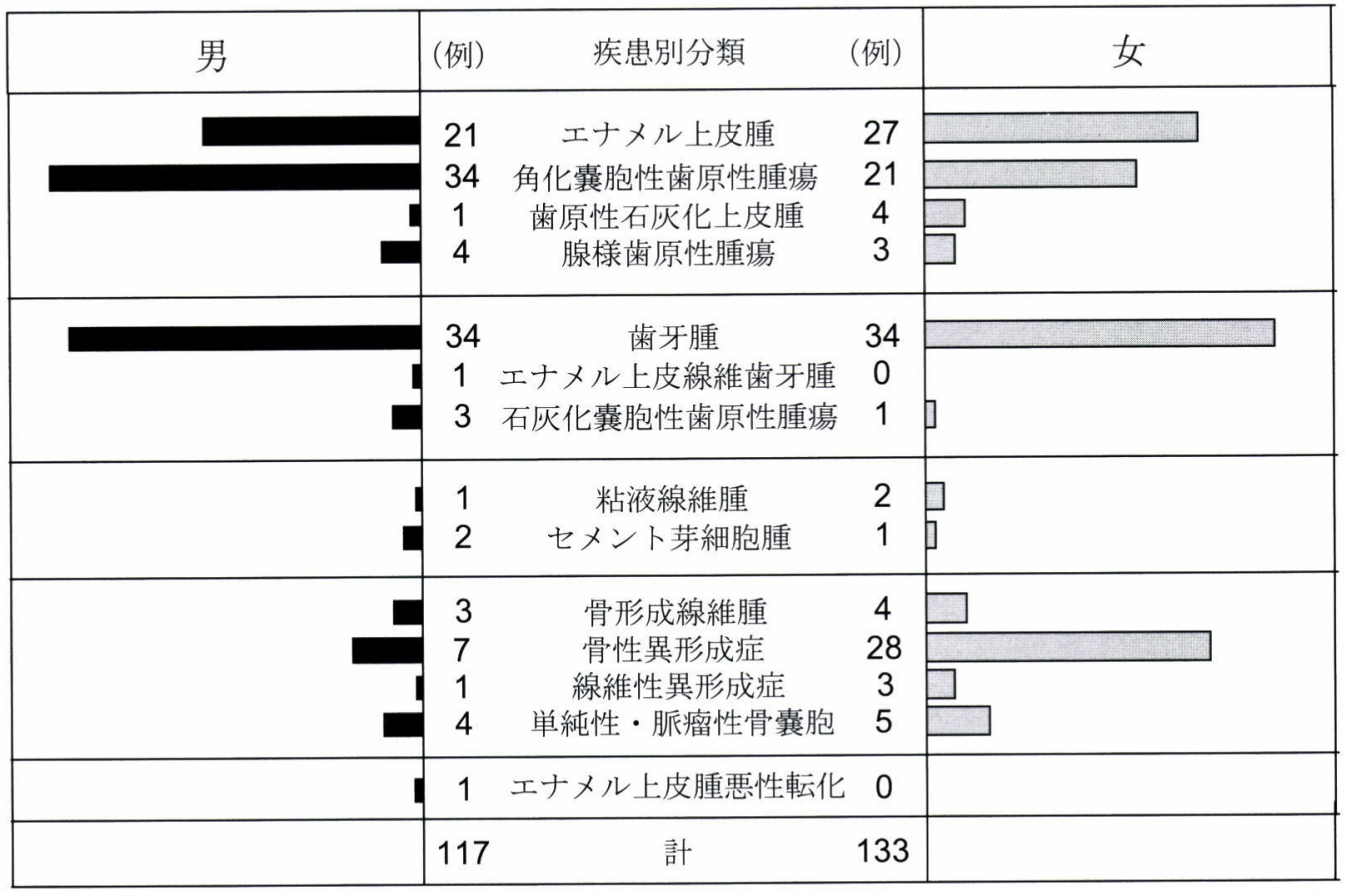

図 2 男女別頻度

\section{2. 性別症例数（図 2)}

歯原性腫瘍全例では, 男性 117 例, 女性 133 例で男女比 は 1：1.14 とやや女性に多かった。歯牙腫では男女とも各 34 例で性差はなく, 角化囊胞性歯原性腫瘍では男性 34 例, 女性 21 例で男女比は $1.62 ： 1$ で男性に多かった。また,
エナメル上皮腫は男性 21 例，女性 27 例で男女比は $1: 1.29$ と女性に多かった。また, 骨性異形成症は男性 7 例, 女性 28 例と男女比 1:4で女性に多かった。その他の症例にお いて性差はなかった。 


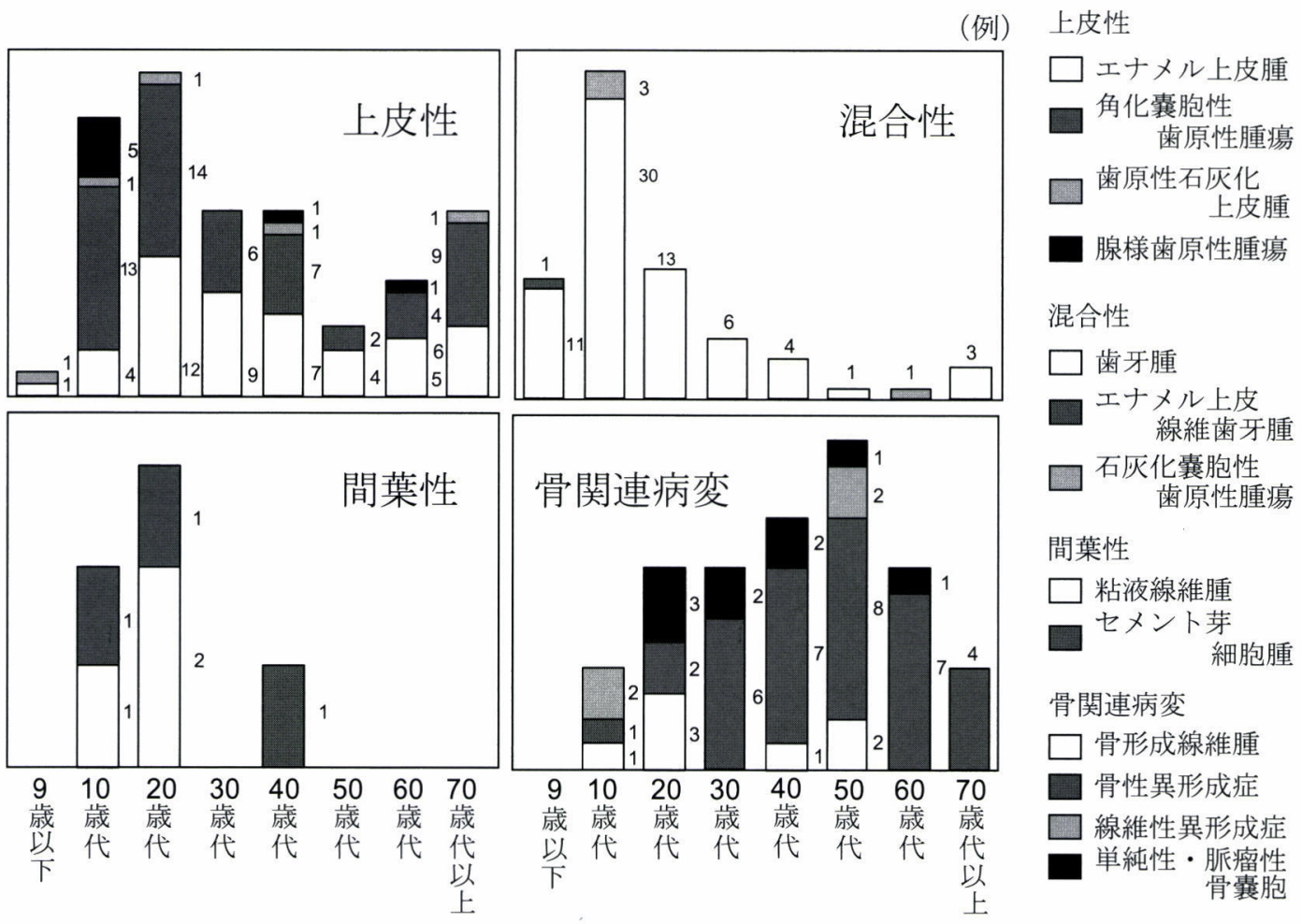

図 3 年齿別頻度

\section{3. 年齢別症例数 (図 3)}

初診時年歯峛 1 歳から 87 歳で, 平均年齢は 34 歳であっ た。歯牙腫は 1 歳から 79 歳にみられ, 平均年歯令は 21.2 歳 であった。歯牙腫の発症年齢で最も多かったのは 10 歳代 の 30 例 $(44.1 \%)$, 次いで 20 歳代の 13 例 $(19.1 \%), 10$ 歳以下の 11 例 $(16.1 \%)$ であり, 70 歳代に 3 例 (4.4\%)あった。 また, エナメル上皮腫では 8 歳から 82 歳で, 平均年齢は 40 歳であった。エナメル上皮腫の発生年齢で最も多かっ たのは 20 歳代の 12 例 $(25.0 \%)$, 次いで 30 歳代の 9 例 (18.8\%)，40 歳代の 7 例（14.6\%）であった。これに対し, 骨性異形成症の発症年踚は 17 歳から 87 歳で, 30 歳代の 6 例 (17.1\%), 40 歳代の 7 例 (20.0\%), 50 歳代の 8 例 (22.9\%), 60 歳代の 7 例 (20.0\%), 70 歳代以上に 4 例 (11.4\%) あり, 平均年齢は 51 歳であった。

\section{4. 主訴別症例数 (表 1)}

主訴では, $\mathrm{X}$ 線撮影による異常を指摘され精査を求め 来院した例が 72 例 $(28.5 \%)$ ，次いで腫脹 60 例 $(24.0 \%)$, 疼痛 49 例 $(19.6 \%)$, 違和感 29 例 $(11.6 \%)$, 萌出異常 29 例 $(11.6 \%)$ であった。腫脹を主訴としたもので最も多かっ たのはエナメル上皮腫 24 例 $(38.7 \%$ ) で, X 線撮影によ る異常を指摘され精査を求め来院したもので最も多かった のは骨性異形成症で 27 例 $(44.2 \%)$ あった。歯牙腫では 27 例 $(39.7 \%$ ）が萌出異常を主訴としていた。

\section{5. 発生部位別症例数（図 4)}

全例の発生部位は下顎が 199 例 $(78.7 \%)$, 上顎が 52 例 (20.8\%) で，特に下顎臼歯部を中心に発生したものが 110 例 $(44.0 \%$ ）と多かった。エナメル上皮腫は 45 例 $(93.8 \%)$ が下顎に発生し，特に臼歯部を中心に下顎枝に発生したも のが 37 例 $(77.0 \%)$ であった。角化輁胞性歯原性腫瘍は 45 例 $(81.8 \%)$ が下顎に発生し， 臼歯部を中心に下顎枝に 発生したものが 43 例（78.1％）であった。骨性異形成症 は全例が下顎に発生し, 臼歯部, 下顎枝に発生したものが 31 例 $(88.6 \%)$ と最も多かった。また, 両側性のものが 5 例 $(14.3 \%)$ あった。線維性異形成症は上下顎臼歯部に 2 例ずつ発生していた。歯牙腫全体では上顎前歯部に 24 例 $(35.3 \%)$, 次いで下顎臼歯部 17 例 $(25.0 \%)$ 発生していた。 集合性歯牙腫は上顎前歯部に 17 例 $(37.0 \%)$, 複雑性歯牙 腫は下顎臼歯部に 12 例（54.5\%）あった。また上下顎臼 歯部に同時に発生した例が 1 例あった。

\section{6. $X$ 線学的腫瘍径 (図 5)}

パノラマX 線写真により計測した病変部の最大径は $5 \mathrm{~mm}$ から $150 \mathrm{~mm}$ で, 平均 $27 \mathrm{~mm}$ であった。エナメル上 皮腫では 30 〜 39mm と 40 ～49mm の大きさが各 $30 \%$ と 最も多く, 最大で $150 \mathrm{~mm}$ であった。角化囊胞性歯原性 腫瘍は 20 ～ $29 \mathrm{~mm}$ が $30 \%$ と最も多く, 最大で $120 \mathrm{~mm}$ で あった。エナメル上皮腫と角化囊胞性歯原性腫瘍は $10 \mathrm{~mm}$ から広範囲に分布していた。歯牙腫は $10 \mathrm{~mm}$ 以下が $30 \%$, 
表 1 主訴別頻度 (例)

\begin{tabular}{|c|c|c|c|c|c|c|}
\hline 組織型分類 & 精査依頼 & 腫脹 & 疼痛 & 違和感 & 萌出異常 & その他 \\
\hline エナメル上皮腫 & 3 & 24 & 13 & 5 & & 開口障害 1 , 腫瘤形成 2 \\
\hline 角化囊胞性崡原性腫瘍 & 12 & 9 & 24 & 8 & & 開口障害 2 \\
\hline 歯原性石灰化上皮腫 & 1 & & 1 & 1 & 1 & 腫瘤形成 1 \\
\hline 腺様歯原性腫瘍 & & 5 & & 1 & 1 & \\
\hline 歯牙腫 & 15 & 8 & 5 & 9 & 27 & 開口障害 1 , 腫瘤形成 3 \\
\hline エナメル上皮線維歯牙腫 & & & 1 & & & \\
\hline 石灰化襄胞性歯原性腫瘍 & & 2 & & 1 & & 腫瘤形成 1 \\
\hline 粘液線維腫 & 1 & 2 & & & & \\
\hline セメント芽細胞腫 & & 1 & 2 & & & \\
\hline 骨形成線維腫 & 2 & 4 & & 1 & & \\
\hline 骨性異形成症 & 27 & 5 & 2 & 1 & & \\
\hline 線維性異形成症 & 3 & & & 1 & & \\
\hline 単純性・脈瘤性骨嚢胞 & 8 & & & 1 & & \\
\hline エナメル上皮腫悪性転化 & & & 1 & & & \\
\hline 計 & 72 & 60 & 49 & 29 & 29 & \\
\hline
\end{tabular}

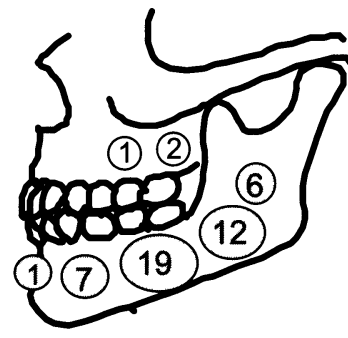

エナメル上皮腫

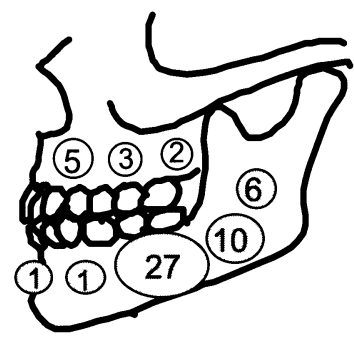

角化囊胞性歯原性腫瘍

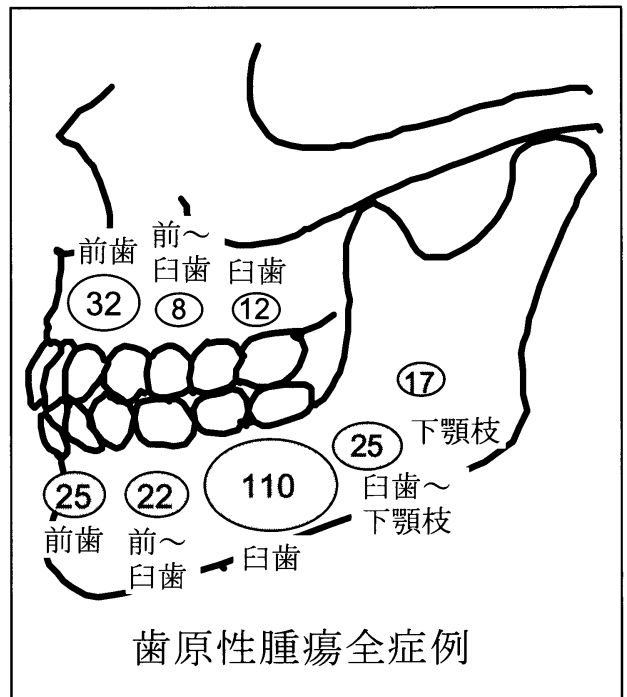

図 4 部位別頻度（例）
10 〜 $19 \mathrm{~mm}$ が $42 \%$ であり，最大で $35 \mathrm{~mm}$ であった。

7. X 線所見（図 6)

$\mathrm{X}$ 線所見は，エナメル上皮腫は多胞性 30 例 $(62.5 \%)$, 単胞性 18 例（37.5\%）の透過像であった。悪性転化した エナメル上皮腫の初診時の X 線所見は多胞性であった。 角化囊胞性歯原性腫瘍は単胞性 44 例 (80.0\%), 多胞性 11 例 $(20.0 \%)$ で単胞性が多かった。

腫瘍に接する歯の歯根吸収が認められたのはエナメル上
皮腫 28 例 $(58.3 \%)$, 角化襄胞性歯原性腫瘍 2 例 $(3.6 \%)$, 歯原性石灰化上皮腫 1 例（20.0\%）で，他の症例には認め られなかった。

歯原性腫瘍と埋伏歯との関連が認められたのはエナメ ル上皮腫 17 例 $(35.4 \%)$, 角化囊胞性歯原性腫瘍 17 例 (30.9\%)，歯原性石灰化上皮腫 1 例 $(20.0 \%)$ ，腺様歯原性 腫瘍 3 例 $(42.9 \%)$, 歯牙腫 29 例 $(42.6 \%)$, 石灰化囊胞性 歯原性腫瘍 3 例 $(75.0 \%)$, 粘液線維腫 2 例 (67.0\%) であっ 
エナメル上皮腫 角化囊胞性歯原性腫瘍 歯原性石灰化上皮腫 腺様歯原性腫瘍

\section{歯牙腫}

エナメル上皮線維歯牙腫 石灰化囊胞性歯原性腫瘍

粘液線維腫

セメント芽細胞腫

骨形成線維腫

骨性異形成症

線維性異形成症

単純性・脈瘤性骨囊胞

エナメル上皮腫悪性転化

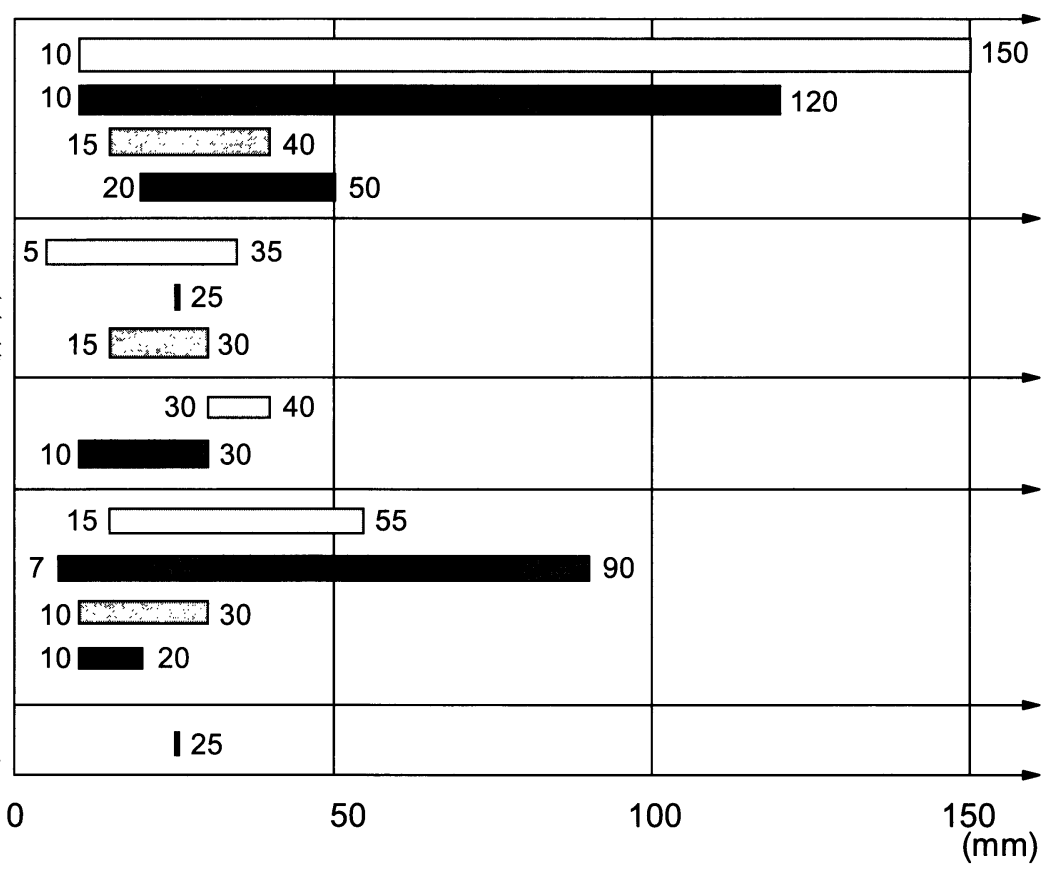

图 $5 \mathrm{X}$ 線学的腫場径

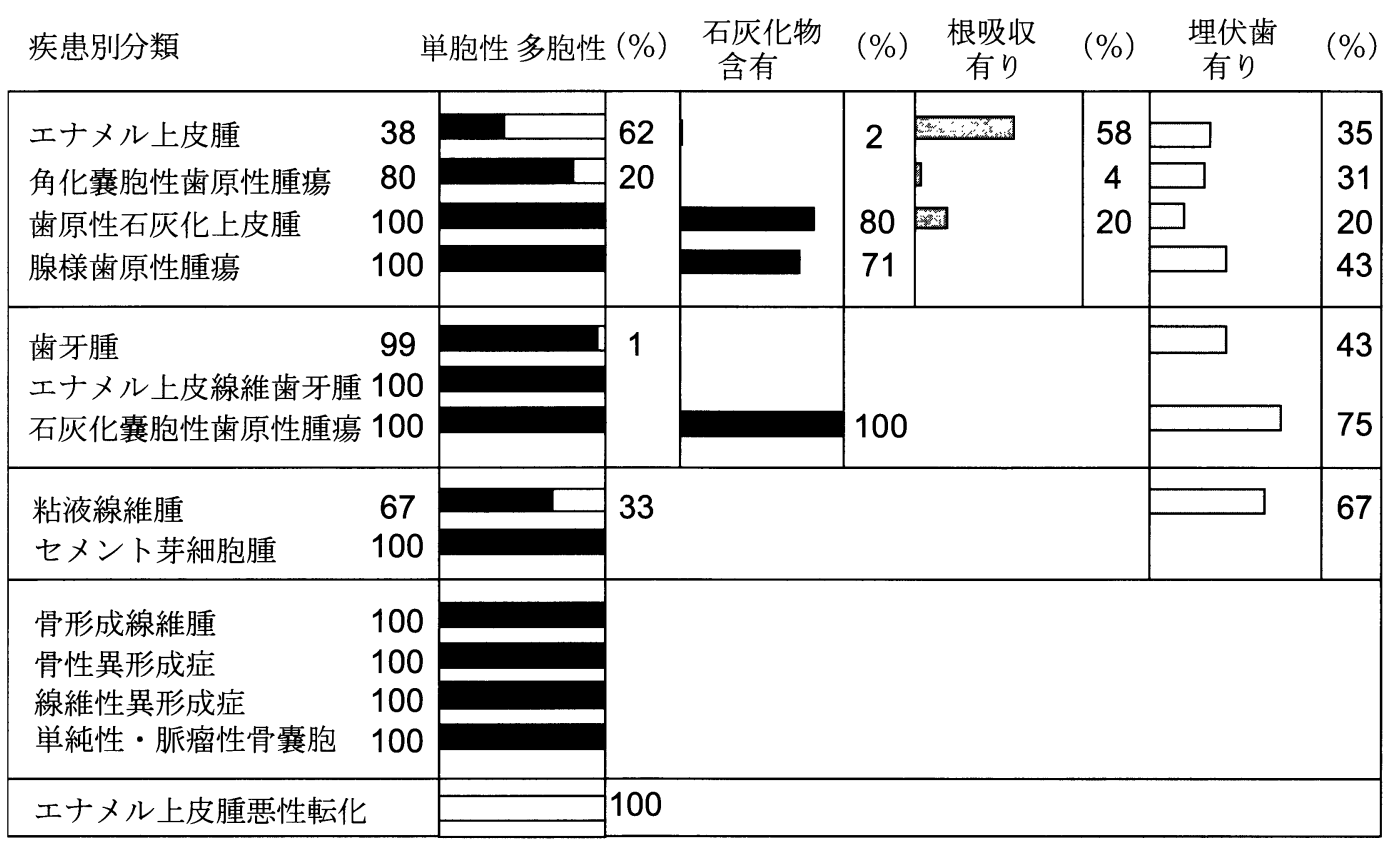

图 6 X 線所見

た。

\section{8. 治療法 (図 7)}

菌原性腫瘍の治療法は，全体では摘出が 187 例（74.8\%） で最も多かった。経過観察のみとなった例や, 生検後全身 状態の悪化などにより治療不可能であったものなど, 治療 を行わなかった例は 19 例（7.6\%）あった。エナメル上皮
腫では, 摘出 19 例 (39.6\%) の他に, 区域切除, 辺縁切除, 開空後摘出が各 8 例 $(16.7 \%)$ で治療を行わなかった例が 5 例 (10.4\%) あった。

\section{9. 術後成績 (図 7)}

再発は歯原性腫瘍 250 例のうち 17 例（6.8\%）に認めら れた。組織型ではエナメル上皮腫 7 例 $(14.6 \%)$, 角化囊 
上皮性
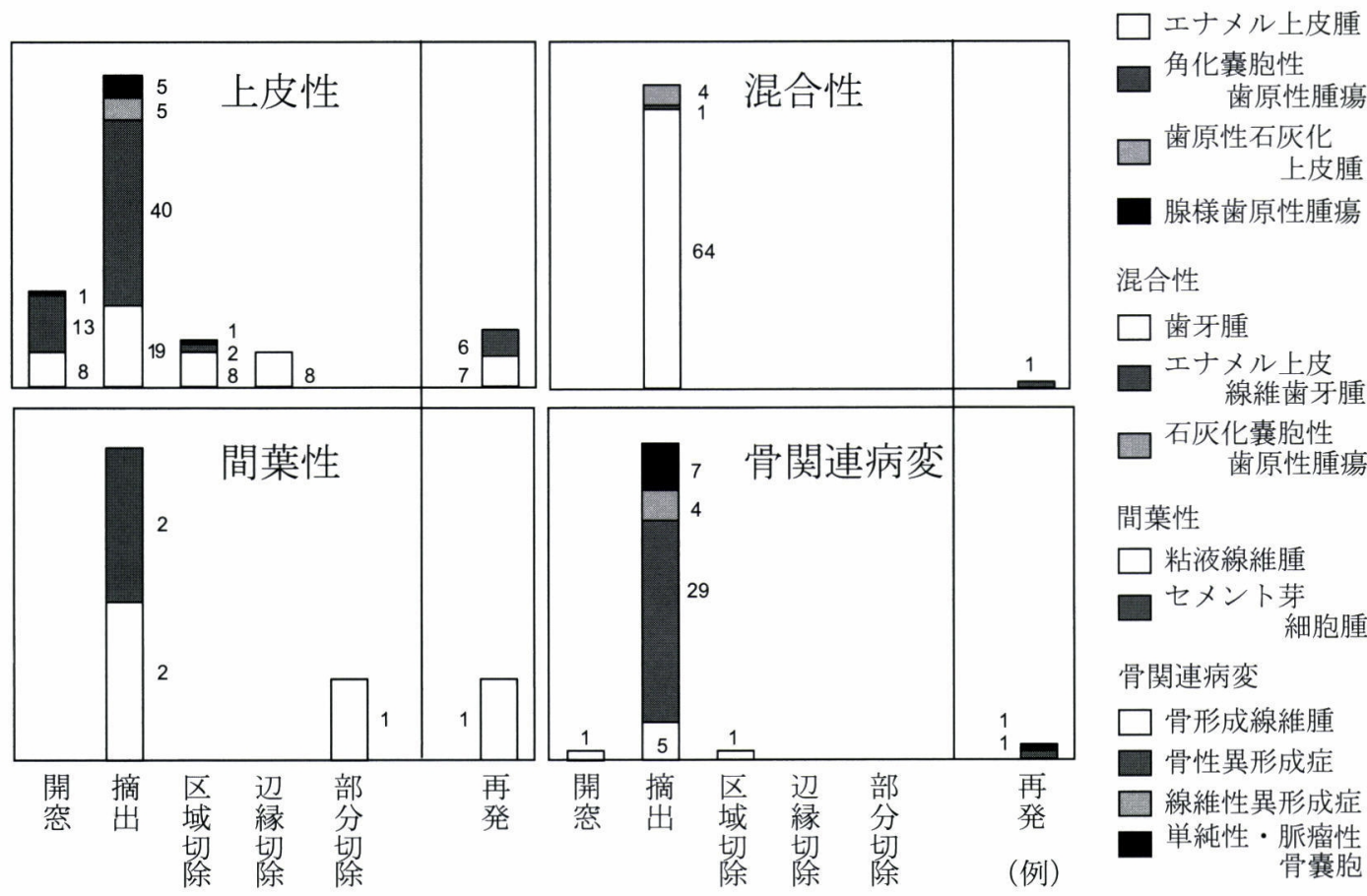

図 7 初回の治療法と再発

胞性歯原性腫瘍 6 例 $(10.9 \%)$, エナメル上皮腫線維歯牙 腫 1 例 (100\%), 骨性異形成症 1 例 $(2.9 \%)$, 脈瘤性骨囊 胞 1 例（11.1\%）に認められた。

\section{考 察}

2005 年に歯原性腫瘍 WHO 国際組織分類 ${ }^{1.2)}$ が改訂され た。今回の新分類では, 臨床的意義を重要視する観点か ら，悪性腫瘍をまず挙げ，次いで良性腫瘍が列記されてい る。悪性腫瘍は歯原性癌腫と肉腫のみとなり, 癌肉腫は削 除された。

良性腫瘍は以前の分類と同様に 1. 上皮性グループ, 2 . 混合性グループ（外胚葉性間葉組織の誘導を伴う上皮性腫 瘍)，3，間葉性グループ，4．骨関連病変，5．その他の腫 瘍に大別された。過去の本邦での歯原性腫瘍の分類の報 告4.5)では骨関連病変が除かれているが, 本研究では上記 新分類に従って統計を行った。本邦における新分類に基づ いた統計報告は渉猟した限りない。

本研究ではエナメル上皮腫悪性転化例が 1 例のみで，一 次症例の悪性腫瘍は経験しなかった。疾患別症例数では, 混合性グループである歯牙腫が歯原性腫瘍全体の $27.2 \%$ （68 例）を占め最も多かった。次いで，新分類で上皮性の グループに変更された角化囊胞性歯原性腫瘍が $22.0 \%$ （55 例）を占めた。過去の報告ではエナメル上皮腫が大部分を
占め, 次いで歯牙腫が多いとするものが多いが3.4), 当科 ではエナメル上皮腫は 48 例（19.2\%）であった。これま での歯原性角化囊胞が腫瘍に分類されたことにより,エナ メル上皮腫, 歯牙腫とならび角化囊胞性歯原性腫瘍が頻度 の高い歯原性腫瘍として位置づけられた。また新分類で は，腺様歯原性腫瘍は混合性腫痬グループから上皮性腫瘍 グループヘ移動しており、これは 7 例みられた。いずれに も間葉組織の誘導はみられず，上皮性腫瘍グループへの移 動は順当であると思われた。また，石灰化歯原性囊胞は腫 瘍的性格を表す名称に変更され，充実性形態と囊胞性形態 を示すものとに分けられた。譲胞型にあたる石灰化囊胞性 歯原性腫瘍は 4 例みられ，充実型にあたる象牙質形成性幻 影細胞腫は当科ではなかった。

骨関連病変として骨性異形成症は 35 例 $(14.0 \%)$ あり， 歯原性腫瘍全体で 4 番目であった。その他，骨形成線維腫 が 7 例, 線維性異形成症は 4 例, 単純性・脈瘤性骨囊胞は 9 例認められた。中心性巨細胞肉芽腫，ケルビズムおよび その他の腫瘍に分類されている乳幼児の黒色性神経外肧葉 性腫瘍は経験しなかった。

歯原性腫瘍全体の男女比は 1：1.14で女性に多かった。 以前の分類での男女比も $1: 1.3$ であり, 新分類と同様に 女性に多かった。1992 年以前では歯原性腫瘍の発生は女 性に多いとされ而，それ以降の報告では男性に多いとさ れているが7-9)，新分類に基づいた本邦での統計は今回が 
初めてである。

発生年齢は 10 歳代と 20 歳代にピークがあるものの, 各年代層に広く分布しており, 従来の報告とほぼ一致し $た^{10)}$ 。特に歯牙腫と角化囊胞性歯原性腫瘍は $10 \sim 20$ 歳代 の若年者に多く, 骨性異形成症は $40 \sim 60$ 歳代の中・高年 者に多くみられた。

部位別頻度では全体では下顎に 199 例 (79.6\%) と多かっ たが, 複雑性歯牙腫は下顎臼歯部, 集合性歯牙腫は上顎前 歯部に多く, 従来の報告 ${ }^{5,8,9)}$ とほぼ一致していた。腺様 歯原性腫瘍は以前の報告では半数以上が上顎, 特に犬歯相 当部に発生したとされていた ${ }^{10)}$ が，当科では下顎に多く， また半数以上が臼歯部に発生していた。

$\mathrm{X}$ 線学的所見では, 多胞性透過像の所見を示す疾患とし ては，エナメル上皮腫 30 例 $(62.5 \%)$, 角化囊胞性歯原性 腫瘍 11 例 $(20 \%)$ ，粘液線維腫 1 例（33.3\%）があった。 また, 腫瘍に隣接する歯に歯根吸収を認めた疾患として は, エナメル上皮腫 28 例 $(58.3 \%)$, 角化囊胞性歯原性腫 瘍 2 例 $(3.6 \%)$, 歯原性石灰化上皮腫 1 例（20.0\%）があっ た。また，小石灰化物である X 線不透過像を含むものが, 石灰化囊胞性歯原性腫瘍 4 例 $(100 \%)$, 歯原性石灰化上皮 腫 4 例 $(80.0 \%)$, 腺様歯原性腫瘍 5 例 $(71.4 \%)$ に認めら れ, 3 疾患ともに半数例が埋伏歯を含み, 単胞性所見を示 していた。このことから，3疾患の鑑別は X 線学的所見の みからでは困難であることが示され, 従来の報告とも一致 していた11)。

骨関連病変を除いて, 一般に歯原性良性腫瘍の治療法 は, 摘出が基本となる ${ }^{5)}$ 。しかし, 局所浸潤性や再発率が 高いとされている疾患は, 大きさや臨床所見, 患者の年齢 等に応じて開空, 摘出や顎骨切除まで様々な治療法が選択 される。今回の検討において, 当科での歯原性腫瘍の治療 法は, 摘出 187 例 $(74.8 \%)$, 開空後摘出 23 例, 区域切除 12 例, 辺縁切除 8 例, 上顎骨部分切除 1 例であった。区 域切除例には全例に腸骨移植を行った。エナメル上皮腫に おいては, 小さな腫瘍および嚢胞性のものでは摘出後閉鎖 創とする術式が比較的多く選択されていた。また，比較的 大きい腫瘍では開空あるいは摘出後開放創が選択された。 開空を選択されたものは透過像の縮小を認め, 骨性支持力 を確保した後で腫瘍摘出術が行われた。それ以外の大きい 腫瘍では顎骨切除術が選択されていた。このうち下顎下縁 の骨皮質が消失もしくは菲薄化し，かつ充実性多胞性を示 した腫瘍は区域切除術を選択し, それ以外は辺縁切除術で あった。なお, 区域切除, 辺縁切除例各 8 例共に再発はな かった。顎骨切除術の選択には, 病変の大きさ, 下顎下縁 への浸潤度, 局所浸潤性の有無, 病変が単胞性か多胞性 か, さらに患者の年齢や全身合併症の有無等を決定因子と し，術式が選択されていた。

角化囊胞性歯原性腫瘍は従来, 歯原性角化囊胞として襄
胞に分類されていたが，改訂された新分類においては，浸 潤性格や再発率の高さから腫瘍として取り扱われている。 当科に扔いても, 角化囊胞性歯原性腫湯を摘出後 23 年経 過し再発した例を含め 6 例 $(10.9 \%)$ の再発症例を経験し た。再発率では準悪性腫瘍とされているエナメル上皮腫の 14.6\%（7 例）に次いで高く, 新分類への移動は順当であ ると思われた。しかし今回, 囊胞壁が正角化を示す角化囊 胞性歯原性腫瘍は 3 例あったものの, この取り扱いは明確 にはされていない。本腫瘍の治療法の選択については, 疾 患の性状を考慮して決定されており新分類の変更による大 きな影響はなく, 開空後病変の縮小を待って摘出を行うよ り, 初回より摘出を選択する方が術後成績は良好と考えら れた。

新分類における骨関連病変の取扱いに関してであるが, 骨様組織の形成を伴った線維性結合組織の腫瘍状增殖を示 す骨形成線維腫は, 境界が明瞭であり歯原性腫瘍と同様の 外科的療法が適用でき, 腫瘍として分類するのは妥当と考 える。一方, 線維性異形成症は, 幼弱な骨梁形成を伴う線 維性結合組織により正常骨組織が置換される疾患で, 病理 学的には骨形成線維腫とは区別が困難であり, 骨の発育異 常によって生じる異形成病変と考えられる。本病変は境界 が不明瞭で, 病変拡大を抑制するための減量療法, あるい は顎骨切除術が選択される。また，骨性異形成症は，同様 に骨の代謝異常によって生じる異形成病変と考えられる が, 境界は不明暸で両側性に発生することも多く, X 線画 像において透過像と不透過像が混在し, 同一患者において も時期により異なる X 線像を示すことも多い。特に二次 的感染をおこした硬化部位は摘出の対象となるが再発をお こすことも少なくない。しかしこれは一般的な再発とは異 なり, 骨代謝異常に陥っている潜在的病变が正常骨組織を 進行性に置換するものと考えられる。

以上より, 骨形成線維腫以外の骨関連病変が腫瘍性病変 に分類されることの妥当性に関しては議論の余地があると 考えられるが, 本研究はこれらを含めた歯原性腫瘍の新分 類に従って検討を行った。

\section{結 語}

当科で 17 年半の間に経験した歯原性腫瘍の患者 250 例 について, 2005 年に改訂された歯原性腫瘍の WHO 国際 組織分類に基づいて臨床統計的検討と文献的考察をして, 以下の結果を得た。

1. 疾患別では歯牙腫が最も多く, 次いで角化囊胞性歯 原性腫瘍，エナメル上皮腫と続いた。

2. 発生部位はエナメル上皮腫, 角化囊胞性歯原性腫瘍, 歯牙腫, 骨性異形成症は下顎の特に臼歯部に多く発生して いた。それ以外の疾患に部位特異性はなかった。 
3. パノラマ $\mathrm{X}$ 線写真により計測した病変部最大径は 5 150mm で, エナメル上皮腫は $30 \sim 49 \mathrm{~mm}$, 角化囊胞 性歯原性腫瘍は $20 \sim 29 \mathrm{~mm}$, 歯牙腫は $10 \sim 19 \mathrm{~mm}$ が最 も多かった。

4. X 線所見ではエナメル上皮腫, 角化囊胞性歯原性腫 瘍, 粘液線維腫が多胞性を示した。

5. 治療法は摘出を基本とし，局所浸潤性のある疾患や 再発率が高いとされている疾患は，摘出，開空後，摘出や 顎骨切除まで様々な治療法を選択した。

\section{引用文献}

1) Barnes, L., Eveson, J., et al.: World Health Organization Classification of Tumors, Pathology and Genetics of Tumors of the Head and Neck. International Agency for Research on Cancer, Lyon, 2005.

2) 武田泰典, 高田 隆：WHOによる歯原性腫瘍の新たな組織 分類．病理と臨床 $23: 867-873 ， 2005$.
3）石川梧朗：歯原性腫瘍について。 口病誌 49 : 555-567, 1982.

4）国芳秀晴，吉田雅司，他：当科における過去 10 年間（1976 1985 年）良性腫瘍の臨床統計的観察. 日口外誌 $35 ： 700-$ 712,1989

5）樋口勝規, 田代英雄, 他：歯原性腫瘍の臨床的検討. 日口外 誌 $36: 1699-1707,1990$.

6) Regezi, J.A., Kerr, D.A., et al.: Odontogenic tumors; Analysis of 706 cases. J Oral Surg $36: 771-778,1978$.

7）和田重人, 岳 麗華, 他：歯原性腫瘍 109 症例の臨床統計. 口腔腫瘍 $12: 47-53,2000$.

8）伊藤弘人, 手塚太加光, 他：当科における過去 20 年間の小 児の口胿腫瘍及び腫瘍性病変に関する臨床統計的研究. 日口 診誌 $16: 9-14,2003$

9）相馬 陽，高木律男，他：歯原性腫瘍の臨床統計的検討：23 年間 110 例について. 日口外誌 $47: 109-112,2001$.

10）今村英夫, 稲井哲郎, 他 : 歯原性腫瘍 56 例の臨床統計学的 分析. 口腔腫瘍 $9: 276-281,1997$.

11）柣木恵一, 渡辺是久，他：複合上皮性歯原性腫瘍の 1 例．診 断病理 $17: 357-360,2000$. 


\title{
Clinical statistical examination of odontogenic tumors according to the new WHO classification in 2005
}

\author{
Hiromi Nishi ${ }^{1)}$, Koichiro Higashikawa ${ }^{1)}$, Hiroshi Shimasue ${ }^{1)}$, \\ Misato Hiraoka ${ }^{1)}$, Miwa Miyauchi ${ }^{1)}$, Shingo Inoue ${ }^{1)}$, \\ Takashi Takata $^{2}$ and Nobuyuki Kamata ${ }^{1)}$ \\ ${ }^{1)}$ Department of Oral and Maxillofacial Surgery, Division of Cervico-Gnathostomatology, \\ Graduate School of Biomedical Sciences, Hiroshima University \\ (Chief: Prof. Nobuyuki Kamata) \\ 2) Department of Oral and Maxillofacial Pathobiology, Division of Frontier Medical Science, \\ Graduate School of Biomedical Sciences, Hiroshima University \\ (Chief: Prof. Takashi Takata)
}

\begin{abstract}
Two hundred and fifty odontogenic tumors retrieved from the file of the Department of Oral and Maxillofacial Surgery in Hiroshima University Hospital (1988-2005) were reclassified according to the new WHO classification revised in 2005 and the clinicopathological data were analyzed statistically. Histologically, the tumors contained 68 odontomas, 55 keratocystic odontogenic tumors and 48 ameloblastomas. These tumors constituted $68.4 \%$ of all the cases. The malefemale ratio of all odontogenic tumors was $1: 1.14$. Seventy-two cases $(28.8 \%)$ had no symptoms but abnormal X-ray photograph. In the cases of odontoma, many patients complained of eruption delay of teeth. Fifty-four percent of all the tumors occurred in the molar region of the mandible. Most of them were treated surgically and their prognosis was good except for the 17 recurrence cases.
\end{abstract}

Key words : odontogenic tumor, new WHO classification, clinical statistical examination

Requests for reprints to: Dr. Nishi H., Department of Oral and Maxillofacial Surgery, Division of Cervico-Gnathostomatology, Graduate School of Biomedical Sciences, Hiroshima University, 1-2-3, Kasumi, Minami-ku, Hiroshima, 734-8553 Japan 